\title{
A challenging central line insertion: where did the contrast go?
}

\author{
Peter Donnelly, Christopher Flannigan, Julie Richardson
}

Paediatric Intensive Care Unit, The Royal Belfast Hospital for Sick Children, Belfast, UK

\section{Correspondence to} Dr Peter Donnelly, pdonnelly00@hotmail.com

Accepted 8 October 2015

\section{CrossMark}

To cite: Donnelly $P$, Flannigan C, Richardson J. BMJ Case Rep Published online: [please include Day Month Year] doi:10.1136/ bcr-2015-212490

\section{DESCRIPTION}

A 2-year-old girl had a femoral central line inserted prior to debulking surgery for an abdominal neuroblastoma. She had a background of recent major surgeries, numerous previous central lines and multiple thrombi in her major vessels. The procedure was technically challenging and a triple lumen central line was sited with difficulty.

All three lumens of the central line flushed easily; however, it was only possible to aspirate dark red, non-pulsatile blood from the distal lumen. Specifically due to the background of multiple thrombi, the decision was made to inject contrast to confirm line position and patency. (Contrast was not used to confirm line position, but rather to assess for possible thrombus proximal to the line tip.)

Two millilitres of contrast was injected and a radiograph (figure 1) was performed. The contrast was, surprisingly, not detectable. The proposed explanation for this finding was that contrast was not captured due either to the timing of the radiograph or because an inadequate volume was injected. A further $5 \mathrm{~mL}$ of contrast was injected, with a radiograph (figure 2) taken towards the end of the injection. This time, a small stream of contrast was noted coming from the line tip and heading distally down the leg.

The line was reviewed and none of the lumens would sample, however, all flushed easily. The line was re-wired to a longer $(12 \mathrm{~cm})$ line and clinically felt to be arterial-confirmed by transducing

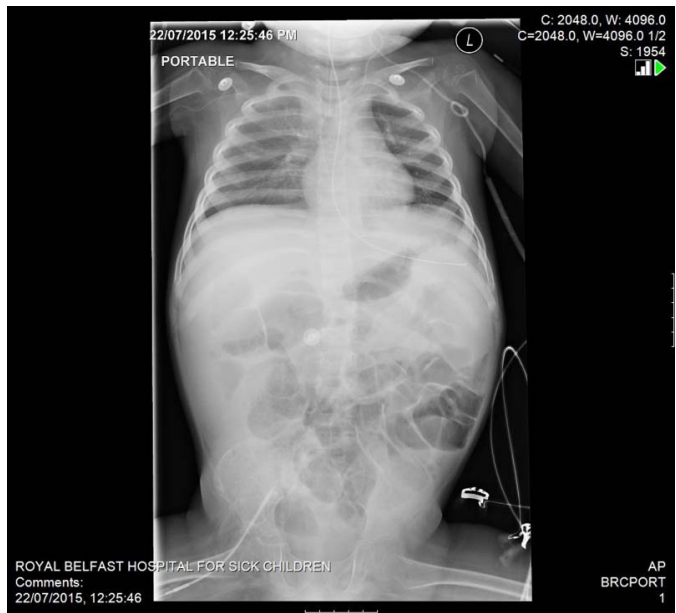

Figure 1 Radiograph demonstrating the absence of contrast proximal to the central line tip.

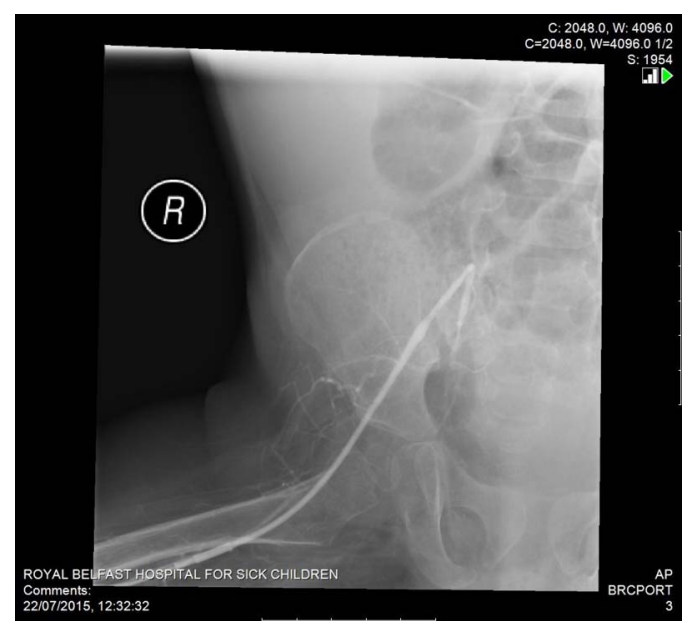

Figure 2 Radiograph showing a small stream of injected contrast coming from the line tip before heading distally down the leg, in keeping with arterial positioning.

the line. Imaging then made sense and the line was removed and re-sited without complication.

\section{Learning points}

- Consider central venous line misplacement when all the lumens do not aspirate and flush freely, particularly on a newly inserted line.

- Contrast, although used for a specific reason in this case (thrombosis), is a useful tool to help confirm line position, however, when contrast is not seen proximal to the line tip, it is important to look for distal vessel contrastsuggesting arterial placement.

- The absence of bright red pulsatile blood flow does not exclude arterial placement of a central line and transduction of the line to confirm position is recommended. ${ }^{1}$

Competing interests None declared.

Patient consent Obtained.

Provenance and peer review Not commissioned; externally peer reviewed.

\section{REFERENCE}

1 Shivappagoudar VM, George B. Unintentional arterial cannulation during cephalic vein cannulation. Indian J Anaesth 2013:57:320-2. 
Copyright 2015 BMJ Publishing Group. All rights reserved. For permission to reuse any of this content visit http://group.bmj.com/group/rights-licensing/permissions.

BMJ Case Report Fellows may re-use this article for personal use and teaching without any further permission.

Become a Fellow of BMJ Case Reports today and you can:

- Submit as many cases as you like

- Enjoy fast sympathetic peer review and rapid publication of accepted articles

- Access all the published articles

- Re-use any of the published material for personal use and teaching without further permission

For information on Institutional Fellowships contact consortiasales@bmjgroup.com

Visit casereports.bmj.com for more articles like this and to become a Fellow 